\title{
The Resources of Kind
}

Genre-Theory in the Renaissance 


\section{UNA'S LECTURES}

Una's Lectures, delivered annually on the Berkeley campus, memorialize Una Smith, who received her B.S. in History from Berkeley in 1911 and her M.A. in 1913. They express her esteem for the humanities in enlarging the scope of the individual mind. When appropriate, books deriving from the Una's lectureship are published by the University of California Press:

1. The Resources of Kind: Genre-Theory in the Renaissance, by Rosalie L. Colie. 1973 


\section{ROSALIE L. COLIE}

\section{The Resources of Kind \\ Genre-Theory in the Renaissance}

Edited by Barbara K. Lewalski

UNIVERSITY OF CALIFORNIA PRESS

Berkeley - Los Angeles $\cdot$ London 
University of California Press

Berkeley and Los Angeles, California

University of California Press, Ltd.

London, England

Copyright (C) 1973 , by

The Regents of the University of California

ISBN: 0-520-02397-8

Library of Congress Catalog Card Number: 72-95307

Printed in the United States of America 